\title{
KONTEKSTUALISASI MAKNA DAN HAK-HAK PEREMPUAN DALAM ALQURAN
}

\author{
Mukarromah \\ STAIN Sultan Abdurrahman Kepulauan Riau \\ hjmukarromah04@gmail.com
}

\begin{abstract}
ABSTRAK
Kajian gender dalam Islam selalu menjadi perhatian karena banyak yang menuduh bahwa agama-termasuk Islam-- kerap kali dituding tidak pro terhadap perempuan. Artikel ini hendak melihat perihal pemaknaan atas terma Alquran tentang perempuan. Dalam penelitian ini, ada banyak kosa kata yang diterdapat dalam Alquran untuk menyebut perempuan, setidaknya ada empat kata yakni nisa', mar'ah, untsa dan banat. Tiga yang pertama merujuk pada perempuan dewasa dan memiliki kerakteristik tersendiri ketika digunakan dalam ayat. Kedewasaan ini pula yang menimbulkan konsekuensi kajian lebih lanjut sebab akan melahirkan karakteristik dan kategori untu perempuan itu sendiri. Berdasarkan karakternya, dalam Alquran disebutkan wanita shalehah, wanita pejuang, penyabar, setia, durhaka, penghianat, penggoda dan sebagainya. Yang tidak kalah penting. Alquran hanya membedakan persoalan perempuan dan laki-laki pada hal kodrati saja, sedangkan pada urusan lainnya, justru perempuan mendapatkan keistimewaan sebagai pengangkatan derajat.
\end{abstract}

Abstract: Gender studies in Islam have always been concerned because many claims that religion, including Islam, is often accused of not being pro-women. This article wold like to the meaning of the Quranic term about women. In this study, there are many words in the Quran that refer to women. There are at least four words, namely nisa', mar'ah, untsa and banat. The first three word refer to adult women and have their own characteristics when they are used in verses. This maturity also has consequences for further studies because it creates the characteristics and categories for women themselves. Based on the character, it is said in the Qur'an that women are pious, hardworking, patient, loyal, rebellious, traitors, teasers and so on. Equally important, Quran only distinguishes women's and men's issues in natural matters. Whereas in other matters, women only get privileges like listing their degrees.

Keywords: nature, women, Islam, gender.

\section{Pendahuluan}

Unversalitas ajaran Islam mampu beradaptasi dan mengakomodir ajaran-ajaran yang berkaitan dengan berbagai aspek kehidupan manusia. Sebagaimana hubungan antara manusia dengan Tuhannya, manusia dengan sesama manusianya, juga manusia dengan alam. Dari berbagai asepek kehidupan ini terjadi suatu ketimpangan dan menjadi bias relasi antara laki-laki dan perempuan di masyarakat pada umumnya. Hal ini terjadi karena kurangnya pemahaman tentang Alquran dan hadis.

Identitas gender dalam perspektif Alquran adalah suatu istilah yang mengakomodir antara laki-laki dan perempuan, gelar, dan status yang berkaitan denan jenis kelamin. Namun dalam Alquran kata ganti (isim dhamir) yang berhubungan dengan jenis kelamin, dan kata sifat, hampir semua itu dibuat dan terbentuk dengan kata mudzakear dan muannast. Hal ini dapat 
dipahami dengan gramatikal bahasa Arab yang memiliki kompleksitas truktur lebih rumit dibandingkan bahasa lainnya. Bahkan, dalam Alquran sendiri terdapat banyak kata ganti 'tersembunyi' yang sering digunakan untuk mendapatkan pemahaman utuh atas ayat.

Dalam kosakata Arab, ada banyak kata bermakna gender, seperti ar-rijal yang artinya orang laki-laki dan an-nisa' yang artinya seorang perempuan. Kata rijal adalah lawan dari annisa', sebagaimana yang tersirat dalam sural AlBaqarah ayat 282. setelah penulis amati ternyata dalam Alquran surat Al-Baqarah ayat 282 memuat kata ar-rajul yang merupakan gender laki-laki dan bias bagi perempuan. Sebagaimana contoh dalam kesaksian. Kata arrajul yang tersirat dalam surat al-Baqarah ayat 282 di atas, walaupun sama berstatus gender namun berbeda sekali dengan kata-kata ar-rijal yang tersirat dalam surat an-nisa' ayat 34 yang mempunyai makna ar-rijal (pelindung dan penanggung jawab dalam sebuah rumah tangga).

Dari gambaran terebut, kontekstualisasi ayat Alquran menjadi menarik karena ia menjadi pedomen muslim sepanjang zaman. Teks Alquran tidak pernah berubah tetapi interpretasinya bisa mengalami perubahan seiring dengan perkembangan peradaban manusia. Beberapa karya tafsir juga memperlihatkan hal demikian dimana produk tafsir klasik kemudian mengalami perubahan makna kontekstual dari produk tafsir pramodern. Begitu juga karya kontemporer yang lebih kontekstual dari pada tafsir klasik. Sahrur mengatakan, Alquran perlu dimaknai sesuai dengan konteks kekinian yang dihadapi oleh umat manusia. ${ }^{1}$ Hal sedana juga disampaikan

${ }^{1}$ Muhammad Shahrur, al-Kitab wa Alquran: Qira'ah Mu'ashirah (Damaskus: Ahali li al-Nasyr wa al-Tauzi', 1992), hlm. 33. Contoh tentang tafsir yang sarat dengan konteks lokal misalnya hasil penelitian Laraswati, Nadia, Syahrullah Syahrullah, and Ahmad Gibson Al-Bustomi. "Karakteristik Perempuan Dalam Tafsir Ayat Suci Lenyepaneun Karya Moh. E. Hasim," Al-Bayan: Jurnal oleh Engineer yang mengajak agar mengupayakan keberlangsungan eksistensi Alquran di tengah perubahan sosial dengan pembacaan kembali atau meninggalkannya. ${ }^{2}$

Beranjak dari latar belakang di atas, artikel ini hendak memfokuskan perihal kajian gender dan Alquran, khususnya terhadap kontekstualisasi atas pemaknaan perempuan dalam pemahaman kontemporer. Secara umum, kajian tentang Alquran dan gender ataupun isu gender dalam Islam telah menarik perhatian banyak penulis sehingga tidak sedikit karya yang berkaitan dengan isu tersebut dihasilkan dan dalam artikel ini sebagiannya akan menjadi rujukan untuk memudahkan dalam menerapkan analisa konten atas beberapa pemaknaan kata yang diperlukan dalam kajian ini.

\section{Terma Perempuan dalam Alquran}

Ada berbagai macam variasi kosa kata yang bermakna perempuan dalam Alquran. Namun beberapa kata tersebut memiliki pemaknaan berbeda satu dan lainnya sehingga tidak bisa menjadi dipandang sama. Keragaman makna dalam setiap kata dalam Alquran itu muncul disebabkan struktur gramatikal teks dan konteks turunnya ayat. $\mathrm{Hal}$ ini menyebabkan para ulama berbeda penafasiran terhadap satu kata yang biasanya bermanka sama. Sedangkan dalam Alquran, sebagaiamana dalam kaidah tafsir disebutkan, bahwa tidak ada kontradiksi dalam Alquran. Artinya, satu kata maupun satu ayat memiliki karakteristik tersendiri, yang bisa bermakna saling muatkan satu sama lainnya.

Sedikitnya ada empat terma yang sering dimaknakan perempuan dalam Alquran, yaitu kata nisa', imra'ah, untsa dan banat. Masing-

Studi Ilmu Al- Qur'an Dan Tafsir 2, no. 1 (June 27, 2017): 57-70.

2 Asghar Ali Enginerr, Hak-Hak Perempuan dalam Islam, terj. Farid W. dan Cici F. (Yogyakarta: Yayasan Bentang Budaya, 1994), hlm. 3

Perada, Vol. 1, No. 1, Juni 2018 
masing kata ini memiliki derefasi berbeda dalam bentuk tunggal dan jamaknya. Secara lebih lengkap, akan dipaparkan satu persatu dari empat kata tersebut sebagai berikut.

\section{Imra'ah}

Yang berasal dari kata mar'ah yang mempunyai makna baik dan manfa'ah. Dari kata mar'ah ini juga bisa menjadi al-mar'u yang mempunyai makna laki-laki sebagaimana dalam Alquran surat Al-Baqarah ayat 102. Kata imra'ah dalam al-Quran diulang sebanyak 26 kali dalam berbagai bentuk ${ }^{3}$, namun kebiasaanyya kata imra'ah tersebut mempunyai makna istri, apakah itu istri solehah maupun tidak. Sebagimana yang telah disampaikan dalam Alquran surat At-Tahrim ayat 11,

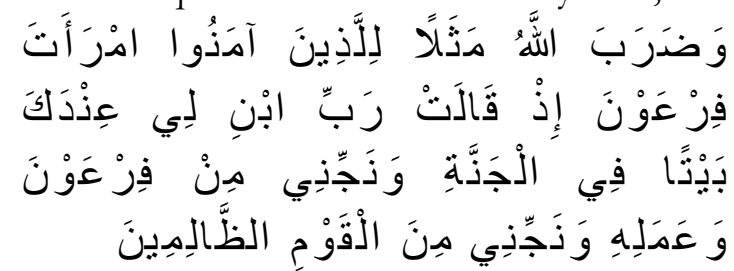

Berdasarkan penelitian penelusuran ternyata kata imra'ah dalam Alquran dapat disimpulkan bahwa kata imra'ah itu bermakna perempuan yang baik. Dalam surat an-naml ayat 23, surat Yusuf ayat 30, al-imran ayat 35, dan al-qasash ayat 9, semua itu mempunyai karakter sebagai wanita pejuang. Disamping sebagai istri, imra'ah juga menjadi wanita yang berkarakter wanita pejuang yang handal. Sebagaimana istri Fir'Aun yaitu asiah, ia seorang perempuan yang menentang suaminya (Fir'aun) demi keyakinan dan akidah yang benar. Disisi lain asiah adalah (imra'ah Fir'aun) yang berkatagori seorang istri yang mandul. Namun kemandulannya itu akan menunjukkan hikmah yang luar biasa.

Di balik itu juga ada seorang perempuan yaitu imra'ah Nuh dan imra'ab Lut. Mereka berdua seorang istri dari kedua para nabi.

3 Noor Huda Noer, Perempuan dalam Perspektif Filsafat Alquran, Al-Risalah. Vol. 10 No. 2, 2010. hlm. 381.

Perada, Vol. 1, No. 1, Juni 2018
Namun kedua perempuan tersebut mempunyai karakter antagonis (tidak setia dan tidak taat pada suaminya). Dari sisi lain ternyata kata imra'ah bukan hanya sekedar menjadi pejuang akan tetapi juga menjadi penaklik (penghambat atas perjuangan yang dilakukan suaminya). Karena itu Allah SWT menimpakan kebinasaan kepada kaum nabi Luth a.s. atas perbuatannya sebagaimana dalam firman allah dalam surat al-a'raf ayat 83-84

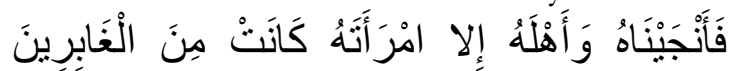

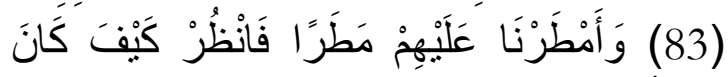

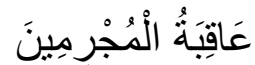

Juga sama hal nya dengan yag tertimpa dapa nabi Yusuf dalam surah yusuf ayat $29^{5}$

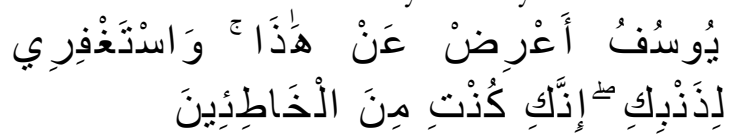

2. An-Nisa'

Al-nisa'berasal dari kata nasa yang mempunyai arti menunda ${ }^{6}$ yang berkaitan dengan tertundanya haid wanita dikarenakan kehamilan. Al-nisa' merupakan jamak dari almar'ah. Term al-nisa' ini bila ditelusuri bentuk tasrifnya (mufrad ke jamak) dapat dikatakan tidak mengikuti kaidah tashrif. Dalam Alquran kata an-nisa ada 57 bentuk. Adapun

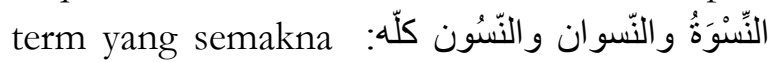

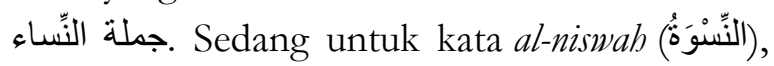
Alquran menyebutnya sebanyak 2 kali, yakni pada QS. Yusuf: 30 dan 50.

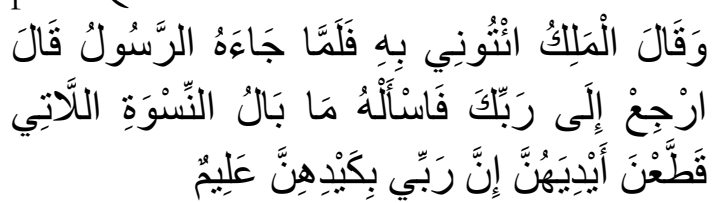

${ }^{4}$ Saleh Qomaruddin,Tafsir Ayatul abkam, Bandung: Dipenegoro, 2006, hal. 653

5 Al-Qarni 'Aidh, Tafsir Muyassar, Jakarta: Qisthi Press, 2008. hal294.

6 Atabik Ali, Ahmad Zuhdi Muhdlor, Kamus Kontemporer: Arab-Indonesia, (Yogyakarta: Multi Karya Grafika, 1996), hlm. 1906. 


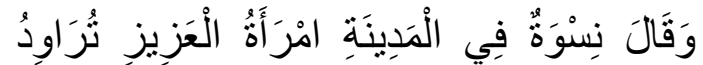

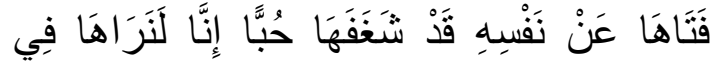 ضَلَالِ مُبِينِ}

Makna yang terkandung dalam kata alnisa' dan al-niswah merujuk kepada komunitas perempuan secara umum, sehingga banyak menjelaskan kehidupan perempuan dalam rumah tangga, bermasyarakat, baik dalam hukum, sosial, serta berbagai aspek lainnya.

\section{Untsa}

Kata untsa dalam Alquran disebutkan 30 kali dalam bentuk yang bermacammacam. Dan keseluruhan itu bermakna perempuan, dan lebih khusus secara biologis. Selain itu, kata untsa selalu bergandengan dengan kata zakar. Penyebutan keduanya mengindiskasikan makna biologis yakni memfokuskan penyebutan pada jenis kelamin. Di antaranya:

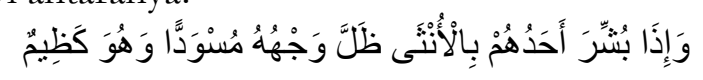

(QS. al-Nahl: 58).

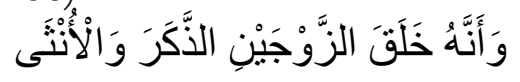

(QS. al-Najm: 45)

Dari keterangan tersebut, menurut Zaitunah Subhan, bahwa lebih menekankan perihal faktor biologis dan kudrati. ${ }^{7}$ Dari pemahaman tersebut dapat diketahui bahwa peranan dan kedudukan laki-laki dan perempuan adalah sama dengan kudrat yang berbeda. Maka, di luar dari dzakar dan unsta, hal itu adalah sebagai bentuk penyimpangan kurdrat.

\section{Banát}

Kata banát disebutkan 17 kali dalam Alquran dengan berbagai bentuk perubahan.

7 Zaitunah Subhan, Al-Quran dan Perempuan, Jakarta: Prenada Media, 2015. hal. 20
Lima ayat di antaranya, yakni QS. al-An'ám: 100, al-Sháffát: 149, dan al-Zukhruf: 16, dan al-Thúr: 39, yang mana menyebutkan anak laki-laki disusul anak perempuan atau anak perempuan dengan anak laki-laki secara berurut. $^{8}$

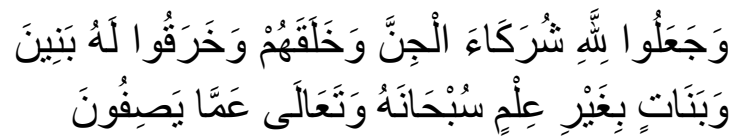

(QS. al-An’ám: 100).

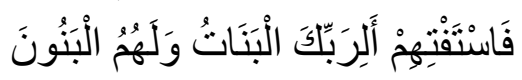

(QS. al-Sháffát: 149).

Semua kata banát dalam Alquran mempunyai makna yang sama yaitu anak perempuan hingga usia baligh, kecuali yang sudah berstatus isteri/janda. Kata banát juga digunakan dalam persoalan pernikahan perempuan (gadis) yang halal dan haram untuk dinikahi, sebagaimana dalam surat al-Ahzáb: 50:

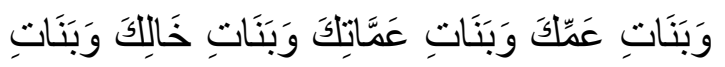

$$
\begin{aligned}
& \text { خَالَالَتَكَ , }
\end{aligned}
$$

dan gadis yang haram dinikahi terdapat pada QS. al-Nisa': 23:

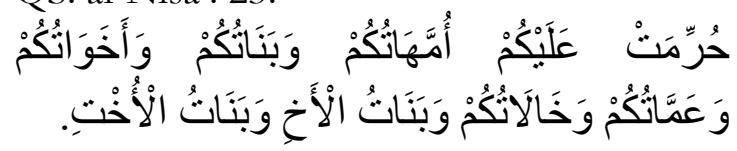

Dari empat kata tersebut terlihat jelas bahwa pemaknaan berbeda-berbeda berdasarkan struktur teks maupun konteks ayat itu sendiri. Selain term-term perempuan yang sudah disebutkan sebelumnya, Alquran juga mengabadikan beberapa nama perempuan, baik disebutkan secara langsung maupun tidak langsung. Alquran secara khusus membicarakan jenis-jenis perempuan berdasarkan amalnya. Kadang-kadang Alquran menunjuk nama dengan jelas jika perempuan yang dilukiskannya adalah perempuan ideal. Untuk mendiskripsikan perempuan yang

\footnotetext{
8 Badan Litbang dan Diklat, "Tafsir Al-qur an Tematik", hlm. 8
}

Perada, Vol. 1, No. 1, Juni 2018 
buruk, Alquran tidak pernah menyebut nama secara langsung. ${ }^{9}$

Alquran memuji perempuan yang membangkang kepada suami yang dzalim. Pada saat yang sama juga Alquran mengecam perempuan yang menentang suami yang memperjuangkan kebenaran. Di antaranya perempuan yang beruntung itu adalah Aisiyah dalam QS. al-Tahrim:11. Tipe Istri yang durhaka pada suami yang dikecam dan diabadikan dalam QS. al-Tahrim: 10, istri Nabi Nuh dan Nabi Luth. Di samping itu disebutkan pula wanita tipe penggoda yang dikisahkan Alquran dalam berkisah tentang Yusuf dan Zulaikha (QS.Yusuf: 23-34).

Adapula nama Maryam juga kerap disebut dengan jelas dalam Alquran. Nama Maryam yang berarti wanita yang taat beribadah, disebut dalam Alquran sebanyak 34 kali dan terbagi dalam 11 surat, baik namanya berdiri sendiri (مريم ابنت عمران) maupun yang bersamaan dengan nama anaknya ( عيسى ابن مريم Bahkan sampai sebuah surat menggunakan nama Maryam. Dan perlu dicatat bahwa tidak seorang wanita pun yang disebut namanya dalam Alquran kecuali Maryam. Ini untuk mengisyaratkan bahwa tidak ada wanita lain yang pernah mengalami melahirkan anak yang menjadi Nabi tanpa disentuh seorang laki-laki. Maryam mendapati gelar atas keshalehan dan kesucian seorang wanita.

Bentuk lain yang digunakan oleh Allah untuk mengungkapkan kata yang merujuk kepada perempuan adalah dengan menambah huruf "ta tamarbuta" di akhir kata pada kata benda (tamarbuta bila tunggal/mufrad

9 Bandingkan juga dengan kajian yang dilakukan oleh Mardan, Simbol Perempuan dalam Kisah Alquran: Suatu Kajian Semiotika dan Teknik Analisis al-Tafsir alMaudu $\square$ i, Makassar: Penerbit, Alauddin Press University, 2014 dalam versi online http:/ / repositori.uinalauddin.ac.id/1643/1/Prof.DR.\%20Mardan\%2C\%20 M.Ag.pdf.

Perada, Vol. 1, No. 1, Juni 2018 dan tamattuha bila

dalam

bentuk jamak). Ta tamarbuta ini

bukan

hanya

digunakan dan ditujukan untuk perempuan tetapi juga digunakan pada benda dan semacamnya.

\section{Kedudukan Perempuan dalam Alquran}

Menurut Quraish Shihab kedudukan perempuan dalam pandangan ajaran Islam tidak diduga atau dipraktikkan oleh sementara masyarakat. Ajaran Islam pada hakikatnya memberikan perhatian yang sangat besar serta kedudukan terhormat kepada perempuan. Menurut Quraish Shihab juga, ada abnyak teks Alquran yang mendukung pendapat yang menunjukkan persamaan unsur terciptanya Adam dan Hawa dan persamaan kedudukannya. Demikian ini terlihat Alquran mendudukkan perempuan pada tempat yang sewajarnya dan meluruskan pandangan yang keliru tentang perempuan dan asal terciptanya perempuan. ${ }^{10}$ Untuk lebih memahami kedudukan perempuan dalam Alquran sebaiknya jika kita mengingat kembali tentang tentang kekejaman yang dilakukan kaum lakilaki terhadap kaum perempuan dalam QS. alNahl: 58-59;

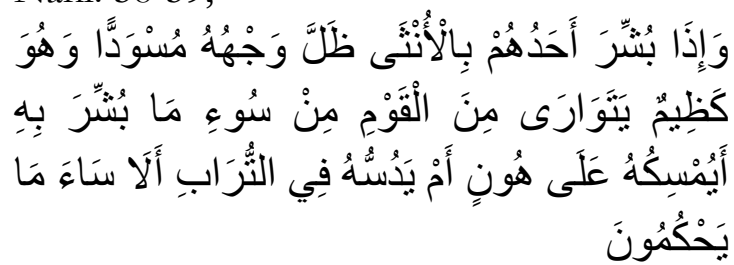

(QS. al-Nahl: 58-59).

Disini dijelaskan bahwa Alquran mengecam perbuatan membunuh anak manusia berjenis kelamin perempuan, kemudian Alquran merubah dan mengganti kebiasaan tersebut dengan menempatkan kedudukan perempuan pada tempat yang sewajarnya dan meluruskan segala pandangan yang keliru yang berkaitan dengan kedudukan dan asal-usul penciptaannya. Kesetaraan asal

10 Qurash Shihab, Wawasan Alquran, (Bandung: Mizan 1996), 303 
usul umat manusia dapat dilihat juga dilihat dalam Alquran yaitu dalam ayat-ayat berikut. Pertama disebutkan bahwa manusia diciptakan dari jenis yang sama; ${ }^{11}$

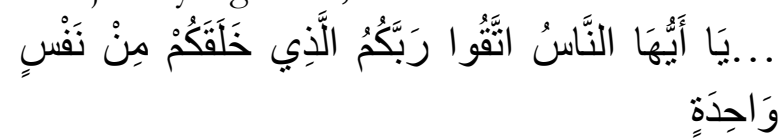

(QS. al-Nisa': 1).

Kedua, bahwa sumber ciptaan manusia adalah laki-laki dan perempuan; ${ }^{12}$

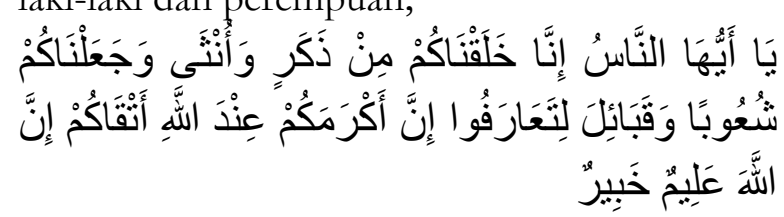

(QS. al-Hujurát: 13).

Quraish Shihab berargumen bahwa tulang rusuk yang bengkok harus dipahami dalam pengertian majaz (kiasan), dalam arti bahwa hadis tersebut memperingatkan kepada para laki-laki supaya menghadapi perempuan dengan bijaksana. Karena ada kecenderungan, sifat, dan karakter perempuan yang tidak sama dengan lelaki, bilamana tidak disadari akan dapat mengantar kaum lelaki untuk bersikap tidak wajar. Para laki-laki tidak akan mampu mengubah karakter dan sifat perempuan. Walaupun jika mereka berusaha, akibatnya akan fatal, seperti fatalnya meluruskan tulang rusuk yang bengkok. ${ }^{13}$

Asghar Ali Engineer mengajukan buktibukti yang menunjukkan bahwa posisi laki-laki dan perempuan dalam agama setara. ${ }^{14}$ Pertama, Alquran memberikan tempat yang sangat terhormat kepada seluruh manusia, baik lakilaki maupun perempuan. Bahwa yang

11 Khoiruddin Nasution, Fazlur Rahman tentang Wanita(Yogyakarta: Tazzafa, 2002), hlm. 23.

12 Khoiruddin Nasution, Fazlur Rabman tentang Wanita(Yogyakarta: Tazzafa, 2002), hlm. 23.

${ }^{13}$ Quraish Shihab, Membumikan Alquran, hlm. 271.

14 Asghar Ali Enginerr, Hak-Hak Perempuan dalam Islam, terj. Farid W. dan Cici F. (Yogyakarta: Yayasan Bentang Budaya, 1994). hal. 43 dan bandingkan juga dengan Khairul Mufti Rambe, "Hak-Hak Perempuan Dalam Hukum Islam (Studi Pemikiran Ashgar Ali Engineer)." JURNAL MERCATORIA 10, no. 2 (December 30, 2017): 109. membedakan antara yang satu dengan yang lain hanyalah ketakwaannya (QS. al-Hujurát: 13) dan bahwa pahala seseorang tergantung pada amal baiknya (QS. Gháfir: 39-40) dan alNisá: 124. Ternyata dalam Islam tidak ada pembedaan yang mutlak antara laki-laki dan perempuan dalam masalah keagamaan. Alquran juga membela prinsip kesetaraan lakilaki dan perempuan. Bahkan Alquran sangat tidak menyukai tradisi masyarakat Arab yang tidak menghargai kelahiran seorang anak perempuan, dan bahkan membunuh mereka (QS. al-Takwir: 9). ${ }^{15}$

Dalam Alquran juga dijelaskan tentang "para wanita yang salehah dan beriman, mu'min̄̄t, muslimāt," dan bahkan menyebut-nyebut mereka dengan nada yang sama dengan para laki-laki yang saleh dan beriman. Lebih-lebih, para wanita ini diharapkan untuk menjalankan kewajibankewajiban agama yang sama sebagaimana lakilaki. ${ }^{16}$ Alquran mendorong semua orang untuk beriman, baik laki-laki maupun perempuan, supaya mereka mengikuti keimanan dengan tindakan, dan untuk ini Alquran menjanjikan pahala ynag besar bagi mereka yang beriman. Jadi Alquran tidak membedakan antara lakilaki dan wanita dalam penciptaan, tujuan, atau pahala yang dijanjikannya. ${ }^{17}$

Berdasarkan Alquran dan hadis serta sejarah umat islam, maka sudah saatnya kaum hawa (perempuan) untuk tampil, bersaing dengan kaum adam (laki-laki) dalam hal kebaikan (fastabiqul khairat) tentunya dengan cara-cara yang terpuji, seperti tetap menjaga harkat dan martabat kewanitaannya. ${ }^{18}$

\section{Hak-Hak Perempuan}

15 Abdul Mustaqim, Epistemologi Tafsir, hlm. 70-71.

16 Annemarie Schimmel, Jiwaku adalah Wanita: Aspek Feminin dalam Spiritual Islam, terj. Rahmani Astuti(Bandung: Mizan, 1998), hlm. 92

${ }_{17}$ Aminah Wadud, Quran Menurut Perempuan, hlm. 51.

${ }^{18}$ Hasbi Indra, Potret Wanita, hlm. 261.

Perada, Vol. 1, No. 1, Juni 2018 
Untuk memahami perempuan dapat melalui penjelasan yang diturunkan oleh Sang pencipta perempuan, firman Allah SWT. Ini merupakan sumber penjelasan terbaik. Alquran berbicara tentang perempuan dalam berbagai surah dan penjelasan tersebut berhubungan dengan berbagai sisi kehidupan. Ada ayat yang berbicara tentang hak dan kewajibannya, ada juga ayat yang menjelaskan tentang perempauan yang shalihah dan tidak. Namun juga ada di antara teks teks Alquran yang berbicara tentang perempuan, sering dipahami sebagaian orang dengan cara yang keliru sehingga menghasilkan kesimpulan yang keliru pula. Diantaranya adalah tentang peran perempuan dalam masyarakat. Ada asumsi yang berkembang dalam masyarakat bahwa perempuan menurut agama tidak mendapatkan tempat dalam kehidupan sosial, peran perempuan hanya sebatas dalam wilayah domestik.

\section{Hak Waris pada Perempuan}

Semula perempuan tidak mendapatkan hak waris dan kebendaan lainnya, karena dianggap tidak cakap untuk mempertahankan qabilah, kemudian secara bertahap Alquran memberikan hak-hak waris tersebut kepada wanita (QS.4: 12). Banyak orientalis yang memandang Islam cacat dan tercela karena memberi jatah hak waris wanita sebagian dari hak waris laki-laki dengan mengacu kepada kalam Allah dalam QS. al-Nisa': ayat 4. Padahal, pernyataan ini bukan pernyataan yang pasti, dan hak waris wanita tidak selamanya separuh dari hak waris laki-laki. Ada beberapa kondisi di mana hak waris mereka sama. ${ }^{19} \mathrm{Hal}$ ini termuat dalam QS. al-Nisa': ayat 11-12.

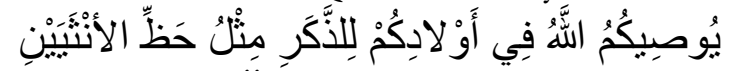

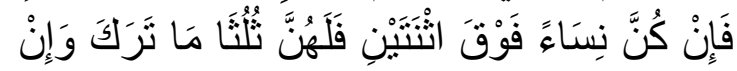

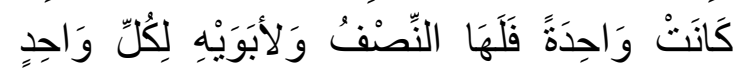

19 Fada Abdur Razak al-Qashir, Wanita muslimah, hlm. 96.

Perada, Vol. 1, No. 1, Juni 2018

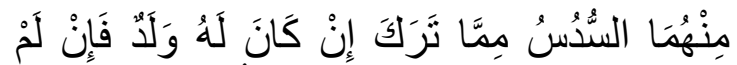

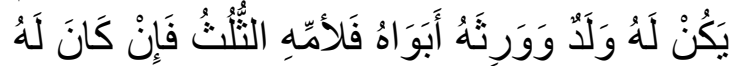

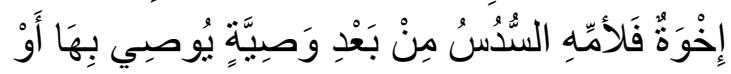

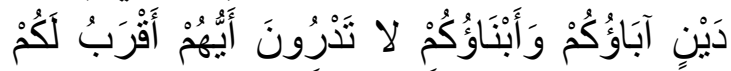

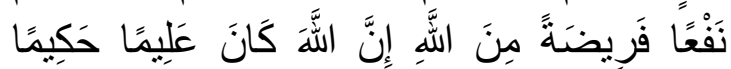

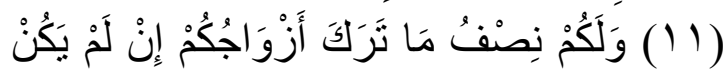

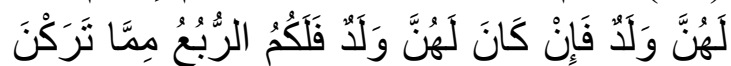

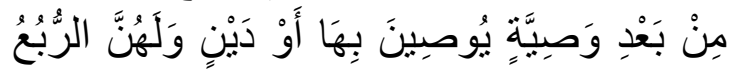

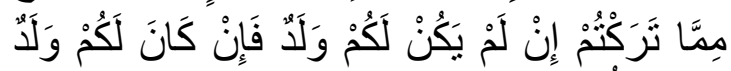

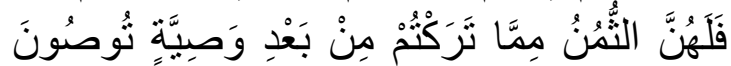

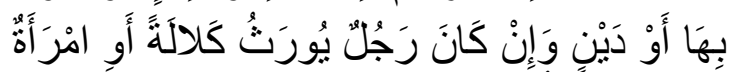

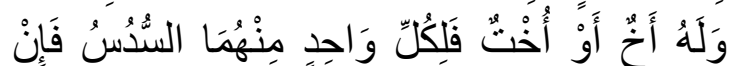

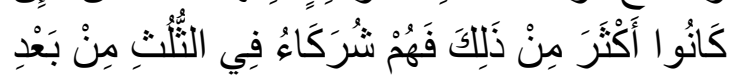

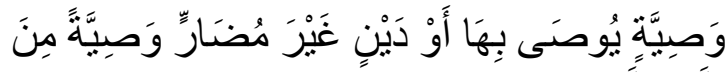

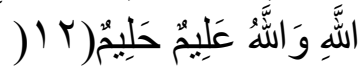

\section{Hak perempuan menuntut ilmu}

Menuntut ilmu adalah suatu kewajiban bagi setiap orang sesuai hadis Nabi saw:

$$
\text { عن أنس بن مالك قال: قال رسول الله صلى اله عليه و }
$$

Perempuan dan hak kepemilikan yang terdapat dalam alquran sama hal nya dengan laki-laki mereka memperolehh atas hasil kerjanya. Alqur an menegaskan dalam surah an-Nisa' ayat 32 sebagai berikut:

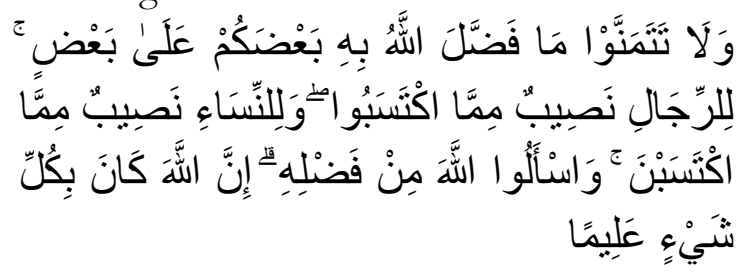

\section{Hak Perempuan Bekerja di Luar Rumah}

Tujuan utama Allah memberikan kesempatan kepada manusia hidup di dunia termasuk perempuan adalah bekerja dengan

20 Abu Abdullah bin Muhammad, Sunan Ibnu Majah. Dalam Program al-Maktabah al-Syamilah. Syeikh Albani berkomentar bahwa hadis ini shahih kecuali redaksi selanjutnya. Begitu pula al-Suyũti yang menanyakan status hadis ini kepada Mahyuddin alNawawi, "status hadis ini lemah dari segi sanad namun dari segi matan shahih. 
baik. Hal ini di isyaratkan dalam Alquran surah al-Muluk. Dalam ayat ini setiap orang baik lakilaki maupun perempuan dituntut untuk dapat mengerahkan kemampuan terbaiknya untuk dapat bekerja dalama bekerja dan melakukan tugas-tugasnya. Ayat yang secara jelas menunjukkan hal tersebut adalah surah al-Nisa ayat 32 .

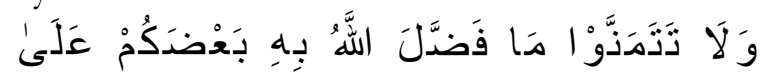

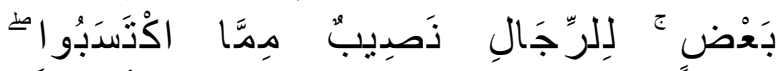

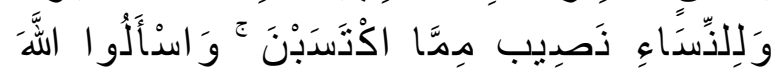

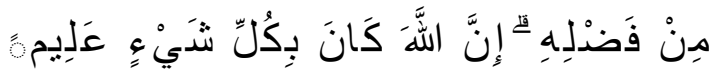

Jika kita pikirkan maka memang benar Islam telah memberikan keadilan yang pantas didapatkan oleh kaum perempuan. Hanya saja tindakanyya di sosial atau publik, dan keluarga yang kurang dimaksimalkan sesuai dengan semangat keadilan yang dibawa oleh Alquran. Munculnya paraa ahli tafsir dari waktu kewaktu yang berbeda itu dcapat membuat hak perempuan kembali terbatasi.

Hak mendapatkan pendidikan dan hak beraktivitas di luar rumah, hak memperoleh pekerjaan, dan hak mendapatkan perlakuan yang baik telah dijelaskan dalam surat anNisa': 19)

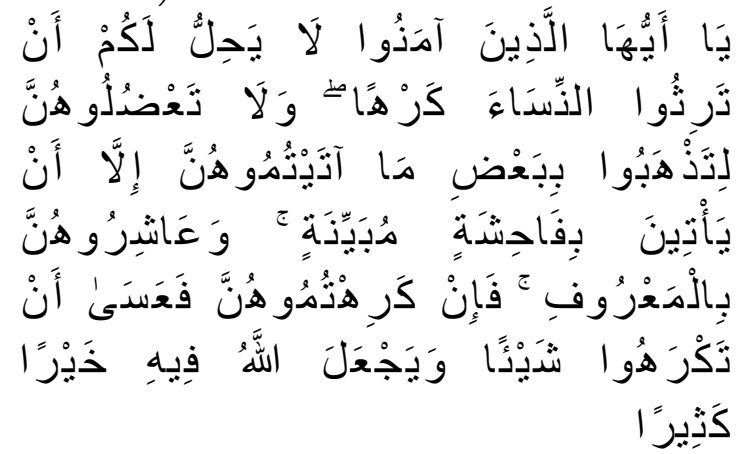

Muhammad Rasyīd Ridhā menjelaskan bahwa ayat ini menunjukkan anjuran untuk kita laki-laki maupun perempuan bekerja dengan baik. Rasyid Ridha menegaskan bahwa bekerja diwajibkan bagi laki-laki maupun perempuan. Allah menunjukkan dan mengarahkan bagi laki-laki maupun perempuan agar bisa menggapai angan-angan dan impiannya dengan bekerja keras dan 8 usaha. ${ }^{21}$ Jadi setiap manusia baik laki-laki maupun perempuan berhak menikmati fasilitas duniawi karena kerja kerasnya.

Terkadang perempuan tersebut memiliki kemampuan yang jarang dimiliki oleh laki-laki. Jadi Pekerjaan yang dilakukannya sebaikanya pekerjaan yang layak bagi perempuan. Begitu juga ketika keluar rumah perempuan harus berpakaian yg sebagaimana mestinya yang dapat menjaga kehormatannya. Perempuan dibolehkan jika memang tidak ada yang bisa mencukupi kebutuhannya dan jika mempunyai suami, belum bisa mencukupi secara penuh, maka dibolehkan untuk bekerja. Kesimpulanya bahwa Alquran tidak melarang seorang perempuan untuk bekerja baik di dalam rumah maupun di luar rumah.

\section{Hak Perempuan dalam Bidang Politik}

Ada beberapa pandangan islam yang menyatakan tentang hak-hak politik perempuan. Seperti, islam tidak mengakui hakhak politik bagi perempuan. Dengan adanya penjelasan dalam Alquran yaitu pada surat alAhzab ayat 33,

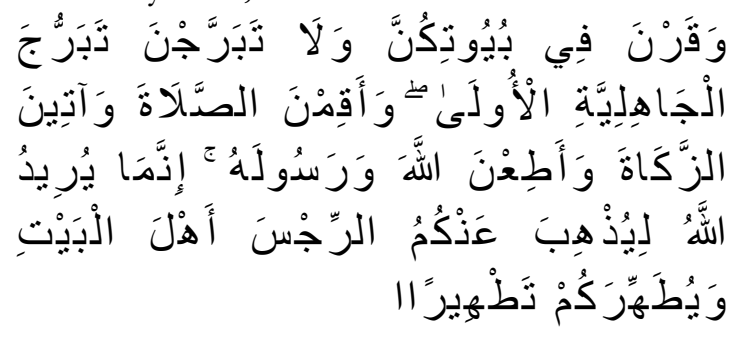

Pada ayat ini dijelaskan bahwa tempat terbaik untuk perempuan hanyalah di dalam rumah. Kemudian ada juga yang menyatakan bahwa islam mengakui hak politik para lakilaki maupun perempuan. Sseperti yan ada dalam surat annisa ayat 34 .

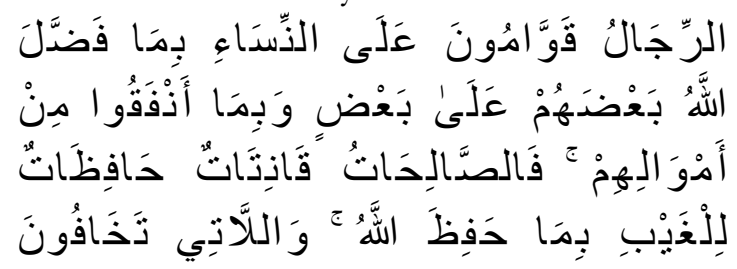
V, 58

${ }^{21}$ Muhammad Rasyid Ridha, Tafsir al-Mannar, Jilid

Perada, Vol. 1, No. 1, Juni 2018 


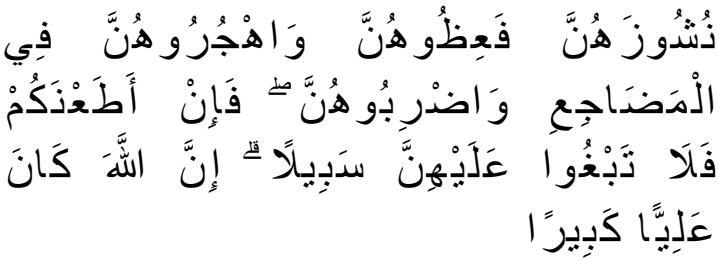

Kesimpulan dari pemahaman seperti ini adalah bahwa perempuan tidak memiliki hak politik yang sama atau setara dengan yang dimiliki kaum laki-laki. Juga ada pandangan yang berpendapat bahwa perempuan memiliki hak politik yang ada di dalam Alquran surat attaubah ayat 71 :

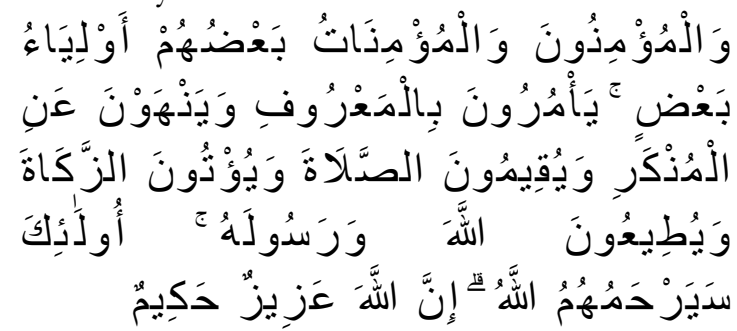

Ketika kaum perempuan menjadi pemimpin dalam kegiatan-kegoatan sosial juga, tidak boleh mengabaikan tugas yang lebih utama sebagai ibu rumah tangga dalam keluarga, dan membangun zurriyah thayyibah (generasi yang ungggul dan baik).

Sedangkan kepemimpinan perempuan dalam Negara, Allah SWT berfirman dalam surah An-naml / 27 ayat 23-24 )

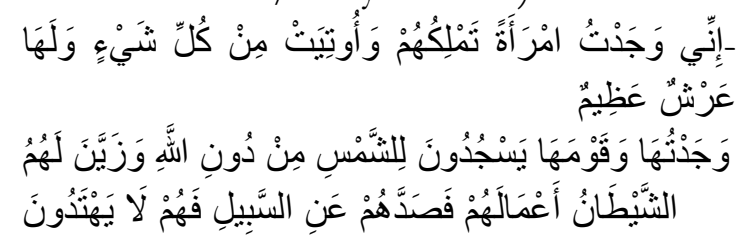

Ayat ini menceritakan bahwa pernah terjadi dalam sejarah kehidupan manusia seorang perempuan memimpin sebuah negara yaitu yang dikenal dengan ratu Bilqis dengan kaumnya bernama kaun saba'. Ayat ini berkaitan dengan peristiwa sejarah dan kita mengetahui sejarah itu tdk dapat dijadikan landasan hukum. Pada ayat itu pula dijelaskan ratu Bilqis yang memiliki kekuasaan yang luar biasa, tetapi dia dan kaumnya tidak beriman kepada Allah, bahkan mereka adalah penyembah matahari.

Perada, Vol. 1, No. 1, Juni 2018
Ayat ini menggambarkan ketidakberhasilan seorang raja perempuan (ratu bilqis) dalam membangun nila-nilai keimanan dan ketauhidan dan tentu akan berdampak pada pembangunan dibidang sosial kemasyarakatan lainya. Bahkan dalam sebuah hadis Rasulullah SAW bersabda yang artinya "tidak akan pernah beruntung (sukses) suatu kaum (bangsa), yang menyerahkan segala urusan (yang dipimpin pada perempuan)"(Riwayat Attirmidzi dari Abu Baakrah).

Meskipun terdapat perbedaan penafsiran terhadap hadis tersebut, penulis berpendapat bahwa dilihat dari tugas dan tanggung jawabnya yang sangat besar, kepala negara atau kepala daerah tidak sepantasnya diberikan kepada kaum perempuan, seorang kepala daerah harus tau betul permasalahan yang dihadapi oleh masyarakat dan bangsanya, ia harus sering melakukan dan memeriksa kondisi dan situasi masyarakatnya sendiri. ${ }^{22}$

Selain mempunyai hak, perempuan juga memiliki berbagai peran dalam kehidupannya seperti Peran perempuan dalam keluarga. Hal ini menjadi kajian yang paling sering dibahas karena masalah domestik rumah tangga dalam persepi umum merupakan tugas perempuan. Sedangkan dalam keluarga, orang tua mempunyai peran penting dalam mendidikan anak. Itu sebabnya Rasulullah SAW mengingatkan betapa peran orang tua (keluarga) dalam membentuk akidah seorang anak awal kehidupanya sangat menentukan. ${ }^{23}$

22 Bandingkan dengan penelitian Yanti Haryani, "Kontribusi Ajaran Islam Tentang Hak Politik Perempuan," MAZAHIB 15, no. 1. Dalam penelitian ini, Yanti melihat antara konteks politik Indonesia dengan kuota minimal 30 persen bagi perempuan. Sebegaimana pendapat penulis di atas, perempuan memang tidak dilarang untuk berpolitik tetapi penulis berpendapat, perempuan kurang layak untuk menjadi kepala atau pimpinannya.

23 Badan Litbang dan Diklat, "Tafsir Al-quran Tematik", hlm 87 


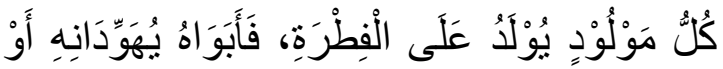

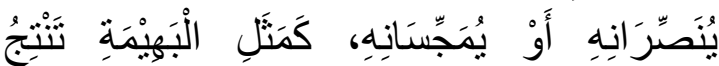

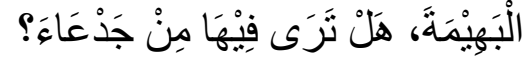

Kata 'fitrah' dalam hadist tersebut diartikan dalam beberapa makna. Sebagaian mengartikan sebagai suci yang siap ditulisi apapun di atasnya. Persisi teori tabularasa (meja lilin) john locke dari aliran positivisme yang menafikkan factor bawaan lahir. Sebagaian lagi memandang bahwa anak lahir sama sekali tidak berarti lahir dalam keadaan kosong sehingga fitrah disitu dimaknai sebagai potensi-potensi yang dibawa sejak lahir. Bahkan, potensi disitu dikaitkan dengan potensi keberimanan sebagaimana dijelaskan dalam surah ar-Rum/30:30 dan al-A'raf/7:172.

Faktor bawaan (potensi) san factor penguatan dari orang tua (keluarga atau lingkungan masyarakat), misalnya melalui pendidikan dan imitasi, menjadi dua factor yang mempengaruhi perjalanan hidup manusia. Bandingkan dengan teori konvergensi, yang menggabungkan antara paham nativisme dan posotivisme sebagaimana diterima dan dipraktekkan dalam dunia pendidikan dewasa ini.

Karena begitu pentingnya peran keluarga dalam membentuk kepribadian anggota dalam kommunitas itu, maka kepala keluarga harus berupaya menjaga kesalehan keluarga yang dimulai dari dirinya sendiri. Anggota keluarga yang datang belakangan akan mengimitasi yang sudah lebih dahulu ada sehingga pembinaan kesalehan keluarga itu harus terus menerus. Allah SWT memerintahkan manusia memelihara diri dan keluarganya dari api neraka (malapetaka) sebagaimana dipahami dari firmannnya dalam surat at-Tahrim/66:6.

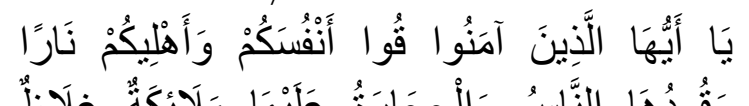

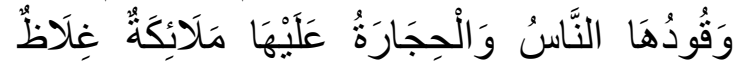

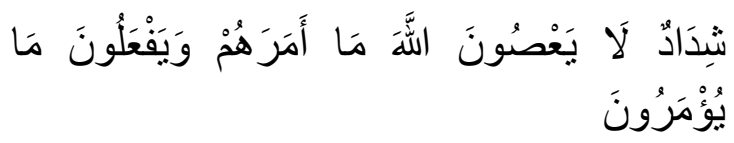

Menurut tabrani, upaya penyelamatan diri dan keluarga daeri api nerakabadalah dengan saling mengingatkan untuk senantiasa taat kepada Allah SWT serta mengajari semua anggota keluarga tentang manusia kedalam api neraka. Kemudian peran perempuan sebagai istri adalah sebagaimana dalam surat an-nur ayat 32

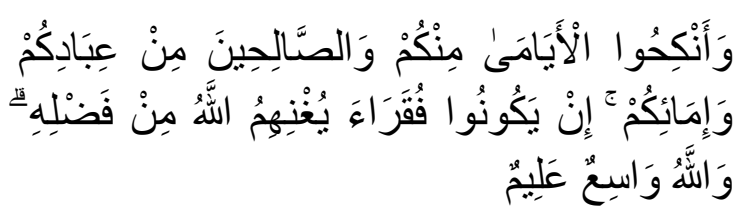

Pada kalimat berarti "dan kawinkanlah orang-orang yang sendirian di antara kalian," lafal ayaama adalah bentuk jamak dari lafal ayyimun artinya wanita yang tidak mempunyai suami, baik perawan atau janda, dan laki-laki yang tidak mempunyai istri; hal ini berlaku untuk laki-laki dan perempuan yang merdeka (dan orang-orang yang layak kawin) yakni yang Mukmin (dari hamba-hamba sahaya kalian yang lelaki dan hamba-hamba sahaya kalian yang perempuan) lafal 'ibaadun adalah bentuk jamak dari lafal 'Abdun. (Jika mereka) yakni orang-orang yang merdeka itu (miskin Allah akan memampukan mereka) berkat adanya perkawinan itu (dengan karunia-Nya. Dan Allah Maha Luas) pemberian-Nya kepada makhluk-Nya (lagi Maha Mengetahui) mereka.

Peran perempuan sebagai ibu adalah sebagaimana yang di terangkan pada ayat alquran surat al-ahqaf/46:15

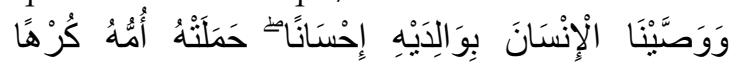

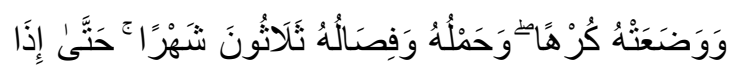

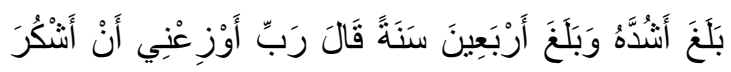

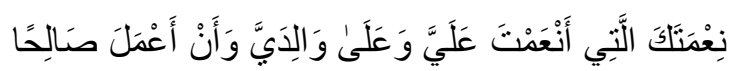

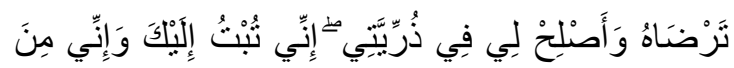

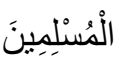


Peran perempuan sebagai ibu, sejatinya dimulai dari saat terjadinya konsepsi (pertemuan sel sperma dan sel ovum) yang berproses menjadi janin dan kemudian harinya lahir sebagai bayi. Sejak itu istri menjalani proses hamil selama beberapa bulan yang cukup melelahkan. Pada tahap ini istri sering dianggap telah berbadan dua, karena ada janin didalam rahimnya. Ia harus memperhatikan kesehatan dan keselamatan dirinya dan juga bayi yang ada dlm kandungannya. Secara garis besar peran sebagi ibu dapat dijelaskan diantaranya sebagai berikut mengandung anak, melahirkan dan menyusui, merawat dan membesarkan anak. Dua yang awal merupakan peran secara kodrati yang tidak mungkin dilakukan oleh laki-laki.

\section{Kesimpulan}

Kajian tentang gender tidak selalu menarik para peneliti untuk mentelaah lebih lebih sekssama, apalagi berhubungan dengan doktrin agama. Islam dan perempuan mendapatkan porsi penting karena ketentuan hukum Islam juga banyak membahasnya, tetapi dalam Alquran sendiri penyebutan untuk perempuan hadir dalam beberapa termaantaranyaal-mar'ah atau al-imra'ah, al-nisa', al-banat, al-untsa, atau menyebut nama tokoh perempuan secara langsung, atau pun menggunakan lambang tamarbutah. Al-mar'ah, al-imra'ah dan al-nisa; pengistilahannya terbatas bagi perempuan dewasa. Kedewasaan ini pula yang menimbulkan konsekuensi kajian lebih lanjut sebab akan melahirkan karakteristik dan kategori untu perempuan itu sendiri. Berdasarkan karakternya, dalam Alquran disebutkan wanita shalehah, wanita pejuang, penyabar, setia, durhaka, penghianat, penggoda dan sebagainya. Namun yang istimewa adalah ketika Alquran menyinggung perempuan dengan karakter antagonis, Alquran tidak menyebutkan nama secara terang-terangan hanya berupa inisial, di mana hikmahnya sebagai pelajaran beretika. Sebaliknya, jika menceritakan prestasi akhlak dan perjuangan yang patut diteladani kaum Hawa maupun seluruh ummat, Alquran menyebut nama secara langsung.

Laki-laki dan perempuan tidak memiliki batas yang pasti dalam hal hukum sosial dan praktik muamalah lainnya. Namun, secara kodrati, ada bagian-bagian yang tidak bisa dilakukan oleh laki-laki dari kodrat perempuan ataupun sebaliknya. Misalnya, perempuanlah yang bisa mengandung, melahirkan dan menyusui, sedangkan lelaki tidak dapat melakukannya. Hal ini sebagai keistimewaan bagi perempuan di banding laki-laki. Dalam ranah publik, perempuan juga memeliki kesempatan yang sama dengan laki-laki, apalagi yang berkaitan dengan menuntut ilmu. Bahkan dalam rumah tanggapun, perempuan juga bisa berberan sebagai penopang ekonomi keluarga bisa kondisi itu memungkinkan dan dikehendahi oleh perempuan. Hal ini mempertegas bahwa Alquran dan dogma ajaran Islam sangat meninggikan derajat perempuan.] 


\section{Daftar Pustaka}

Departemen Agama RI, Alquran al-Karim dan Terjemahnya, Semarang: Karya Toha Putra, 1996.

Lajnah Pelatihan Mushaf Al-Quran Badan Litbang Agama RI , Tafsiral-Maudbu'i (Tafsir Al-Qur'an Tematik), Kamil Pustaka 2014.

Atabik Ali, Ahmad Zuhdi Muhdlor, Kamus Kontemporer: Arab-Indonesia (Yogyakarta: Multi Karya Grafika, 1996).

B, Nurhayati, and Mal Al Fahnum, "Hak-Hak Perempuan Menurut Perspektif Al-Quran." Marwah: Jurnal Perempuan, Agama Dan Jender 16, no. 2 (December 27, 2017): 186. doi:10.24014/marwah.v16i2.4139.

Haryani, Yanti, "Kontribusi Ajaran Islam Tentang Hak Politik Perempuan," MAZAHIB 15, no. 1 (December 28, 2016). doi:10.21093/mj.v15i1.614.

Khoiruddin Nasution, Fąlur Rahman tentang Wanita, (Yogyakarta: Tazzafa, 2002).

Laraswati, Nadia, Syahrullah Syahrullah, and Ahmad Gibson Al-Bustomi. "Karakteristik Perempuan Dalam Tafsir Ayat Suci Lenyepaneun Karya Moh. E. Hasim” Al-Bayan: Jurnal Studi Ilmu AlQur'an Dan Tafsir 2, no. 1 (June 27, 2017): 57-70. doi:10.15575/al-bayan.v2i1.1809.

Mardan, Simbol Perempuan dalam Kisah Alquran: Suatu Kajian Semiotika dan Teknik Analisis al-Tafsir al-Maudu'i, Makassar: Penerbit, Alauddin Press University, 2014 dalam versi online http:/ / repositori.uin-alauddin.ac.id/1643/1/ Prof.DR.\%20Mardan\%2C\%20M.Ag.pdf

Noor Huda Noer, Perempuan dalam Perspektif Filsafat Alquran, Jurnal Al-Risalah. Vol. 10 No. 2, 2010.

Qomaruddin, Saleh, Tafsir Ayatul abkam, Bandung Dipenegoro 2006

Rambe, Khairul Mufti, "Hak-Hak Perempuan Dalam Hukum Islam (Studi Pemikiran Ashgar Ali Engineer)," JURNAL MERCATORIA 10, no. 2 (December 30, 2017): 109. doi:10.31289/mercatoria.v10i2.1095.

Schimmel, Annemarie, Jiwaku adalah Wanita: Aspek Feminin dalam Spiritual Islam, terj. Rahmani Astuti (Bandung: Mizan, 1998).

Shihab, Quraish, Membumikan Al-Quran, Bandung Mizan 1996

Shihab, Qurash, Wawasan Alquran, Bandung: Mizan, 1996.

Subhan, Zaitunah, Al-Quran \& Perempuan, Jakarta: Prenada Media, 2015. 